\title{
Erratum to: Unilateral lacrimal fistula in a patient with uterus didelphys and renal agenesis
}

\author{
Ece Turan-Vural · Fatih Atmaca · Cihan Unlu • \\ Gurkan Erdogan · Huseyin Bayramlar
}

Published online: 7 October 2014

(C) Springer Science+Business Media Dordrecht 2014

Erratum to: Int Ophthalmol (2012) 32:67-69

DOI 10.1007/s10792-011-9510-4

The surname Bayramalar is not correct. It should read:

Bayramlar.

The online version of the original article can be found under doi:10.1007/s10792-011-9510-4.

E. Turan-Vural $(\bowtie)$

Ophthalmology Clinic, Haydarpasa Numune Education and Research Hospital, Istanbul, Turkey

e-mail: dreceturan76@yahoo.com

F. Atmaca - C. Unlu - G. Erdogan · H. Bayramlar

Ophthalmology Clinic, Umraniye Education and Research

Hospital, Istanbul, Turkey 